\title{
PHYSICAL EDUCATION IN GEDIMINAS TECHNICAL UNIVERSITY IN VILNIUS
}

\section{WYCHOWANIE FIZYCZNE NA WILEŃSKIM UNIWERSYTECIE TECHNICZNYM IM. GIEDYMINA}

\author{
Stanislav Dadelo ${ }^{1(\mathrm{~A}, \mathrm{~B}, \mathrm{C}, \mathrm{D}, \mathrm{E}, \mathrm{F})}$ \\ ${ }^{1}$ Gediminas Technical University in Vilnius, Lithuania
}

Authors' contribution Wkład autorów: A. Study design/planning zaplanowanie badań B. Data collection/entry zebranie danych C. Data analysis/statistics dane - analiza i statystyki D. Data interpretation interpretacja danych E. Preparation of manuscript przygotowanie artykułu F. Literature analysis/search wyszukiwanie i analiza literatury G. Funds collection zebranie funduszy
Tables: 0

Figures: 6

References: 23

Submitted: 2017 Jul 17

Accepted: 2017 Oct 04

\section{Summary}

Background. The following study examines the physical education system in Vilnius Gediminas Technical University (VGTU) and its students' health condition. The purpose of the research was to analyse and determine the students' health condition in the years 2008-2013 and their attitudes to elective physical education courses.

Material and methods. The study involved students of the first-degree studies of the VGTU (1st-4th year). The research was conducted in the academic years 2005-2013 and comprised students who chose optional physical education courses and all the first year undergraduates. Results. The studies showed that about $60 \%$ of the VGTU students were healthy with boys demonstrating better health indicators than girls. The most common disorders encountered in the students concerned the visual, cardiovascular and motor systems, which significantly affected their physical activity.

Conclusions. Disorders of the motor system might impact the choice of optional physical education courses the most. An assumption was made that such choice could foster student aspirations in reducing this condition. However, the proposed solution required more thorough research as a well-organised and appropriate physical education programme which might motivate more interest in PA and ultimately help solve problems related to the Lithuanian students' health.

Keywords: students, choices, health, health disorders

\section{Streszczenie}

Wprowadzenie. Obiektem badania był system wychowania fizycznego na Wileńskim Uniwersytecie Technicznym im. Giedymina w Wilnie (WUTG) oraz stan zdrowia studentów. Celem badań była analiza i uogólnienie stanu zdrowia studentów w latach 2008-2013 oraz ich stosunek do sylabusów fakultatywnych wychowania fizycznego.

Materiał i metody. Badane osoby: studenci studiów dziennych I stopnia WUTG (I-IV rok). Badania przeprowadzono w latach akademickich 2005-2013. Badania objęły studentów, którzy wybrali fakultatywne sylabusy na kierunku wychowania fizycznego i wszystkich studentów pierwszego roku dziennych studiów pierwszego stopnia.

Wyniki. Badania wykazały, że na WTUG studiuje około $60 \%$ zdrowych studentów, i że chłopcy w porównaniu do dziewcząt wyróżniaja się lepszymi wskaźnikami zdrowia. Wśród studentów dominują zaburzenia systemu wzroku, układu sercowo-krążeniowego, ruchowoopornego, które istotnie wpływają na czynności fizyczne.

Wnioski. Zaburzenia systemu ruchowo-opornego mogą mieć największy wpływ na decyzję wyboru modułów sylabusów wychowania fizycznego. Wybór ten może sprzyjać aspiracjom studentów w redukowaniu tego zaburzenia. To założenie wymaga dokładniejszych badań. Dobrze zorganizowany i kierunkowo przygotowany program wychowania fizycznego, motywujący do aktywności fizycznej studentów może sprzyjać rozwiązaniu problemów związanych ze zdrowiem studentów na Litwie.

Słowa kluczowe: studenci, wybór, zdrowie, zaburzenia zdrowia 


\section{Introduction}

A society health condition depends on a multitude of internal factors (personal qualities) and external ones (the environment). All these factors that affect the society as a whole, as well as the individual, determine social health. On this basis, one could distinguish three components of a healthy lifestyle: 1) physical health - optimal functioning of the body; 2) mental health - one's self-awareness of their own personality as a whole in which mental and physical functions harmonise; 3) social health - historically formed norms as a whole which positively affect the society in general and each individual [1].

Researchers perceive these components of a healthy lifestyle as closely intertwined and affecting the state's management systems at the social, economic and political levels. The effectiveness of the public health management is a prerequisite for efficient government's work [2,3]. Improving the health condition of children and young people is a priority in striving for a healthier society. Students are the most active members of any community and, at the same time, the basis of the state's future. Accordingly, proper student health is an essential element in preparing future qualified professionals. Unfortunately, many researchers underline that the health condition of children and adolescents is continually deteriorating $[4,5]$. Students can be classified as a group living an extreme lifestyle associated with increased risk for health problems [6]. Consequently, the time when they acquire knowledge becomes a dangerous and challenging period for young people, which additionally affects their psychomotor, social and personal development, which in turn determines later development of their personalities in the subsequent stages of life [7].

Inturn, acquiring the specific characteristics needed in any profession is strictly defined. The process of developing and shaping these properties results from the adaptation of the organism to the process of in which professional skills are acquired. This may indicate that students' education should be comprehensive and that physical activity is essential. Thus, building a system of values through physical activity should not only be pragmatic and momentary. It should also become a moral and intellectual tool that provides the basis of social values. Occupational requirements are adapted to the concept of psychomotor competence: a complex of specific motor, mental and mental abilities in particular occupations or life situations [8]. The social, physical and psychological development of young people in Lithuania differs from that of young people living in other countries. This is caused by the following factors: social environment, economic conditions, occupational and psychomotor skills. It is therefore essential to establish indicators determining health status and criteria for students in Vilnius Gediminas Technical University (VGTU).

\section{Material and methods}

The research material of the study comprised the VGTU physical education system and its students' health condition. The study aimed to analyse and present students' health condition in the years 2008-2013 and its relation to the additional physical education courses. It was hoped that the information about the health of the academic youth would help to optimise the management of their physical activity classes and form a basis for improvement of the youth's physical condition itself. The study was to identify, summarise and compare the results of consistent research $[5,7,9]$.

The examined persons were the first-degree students of the VGTU (1st-4th year). The research was conducted in the academic years 2005-2013. The study covered students who chose additional elective PA courses as well as all the first year undergraduates.

As a research method, case studies (documentation, questionnaire) were conducted, which identified motives, attitudes and attitudes towards educational issues. The students' health condition was assessed by examining the certificates issued by the Lithuanian healthcare institutions (no. 027 / A; no. 046 / A; no. 086 / A). The students were differentiated following the nature of the health disorders of particular systems (visual, motor, cardio-circulatory, respiratory, gastrointestinal, nervous, endocrine and other health disorders) as well as by the severity of the disorders [10]:

The main group (the healthy persons) showed minor health disorders (low-level disorders that do not affect their performance). Students were able to follow the programme of physical education successfully.

The next group, i.e. the preparatory one, showed minor health disorders. The students were physically poorly developed and poorly physically prepared (after severe illnesses or temporarily unable to participate in PE classes). They would engage in physical activity, as indicated in their study programme, provided that such physical activity did not impair their health and would help them to improve its condition. They would not do some exercises and limit others. These students could participate in general physical exercise sessions or do self-training at home after consulting a specialist.

The third group, i.e. the special one, comprised those students with permanent or temporary mild health disorders. They would be involved in individualised physical exercise as they attended a unique programme of 
physical education, and a part of that course was conducted by a specialist in kinesis therapy (sports holidays, leisure trips, etc.).

Finally, there was a group exempted from physical education classes. It concerned all the students who were unable to participate in physical training, as they suffered from chronic illness (sub-compensatory stage), had morphological disorders (complicate daily activities: complications of the cardiovascular system, kidneys, lungs and other systems), and severely sick patients at decompensation stage). The students could do physical activity only in healthcare institutions under the supervision of kinesis therapists.

Summing up, taking into account the characteristics of the groups together and the particular health disorders, it is worth mentioning that the group characterised as the one with disorders significantly affecting the physical activities included the special group (the third one) and the one exempted from physical education comprised those and those exempted from PA.

The indicators of the study are expressed in absolute and percentage values. The significant differences between the calculated indices were measured using the chi-quadrant ( $\chi 2)$ using a $2 \times 2$ table. In determining the reliability of the indicators, the criterion $\mathrm{p}<0.05$ was assumed. Pearson's linear correlation coefficient (Pearson) was calculated to determine the relationship between the variables.

\section{Results}

While assessing the change in the pattern of students with health disorders significantly affecting physical activity in the years 2005 - 2013 (Fig. 1) significant differences were not established.

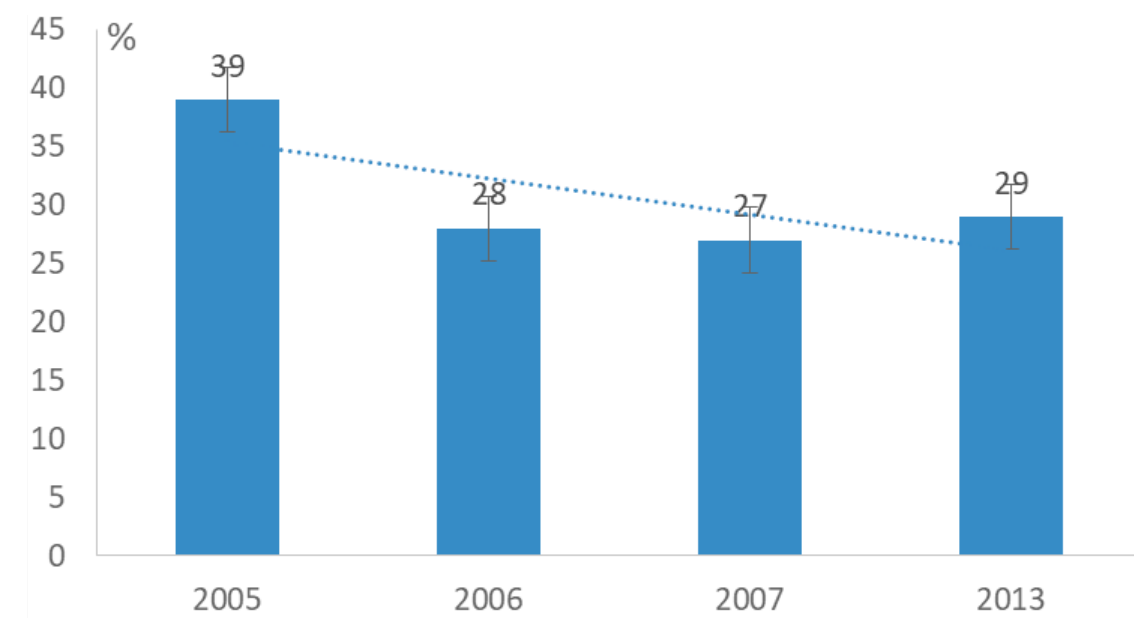

Figure 1. Students with health disorders significantly affecting their physical activity

$31 \%$ of the VGTU students belonged to this group. However, there were significantly more girls who represented the special group and those who were exempted from physical education (on average $41 \%$ ) than boys (on average 26\%) (Fig. 2).

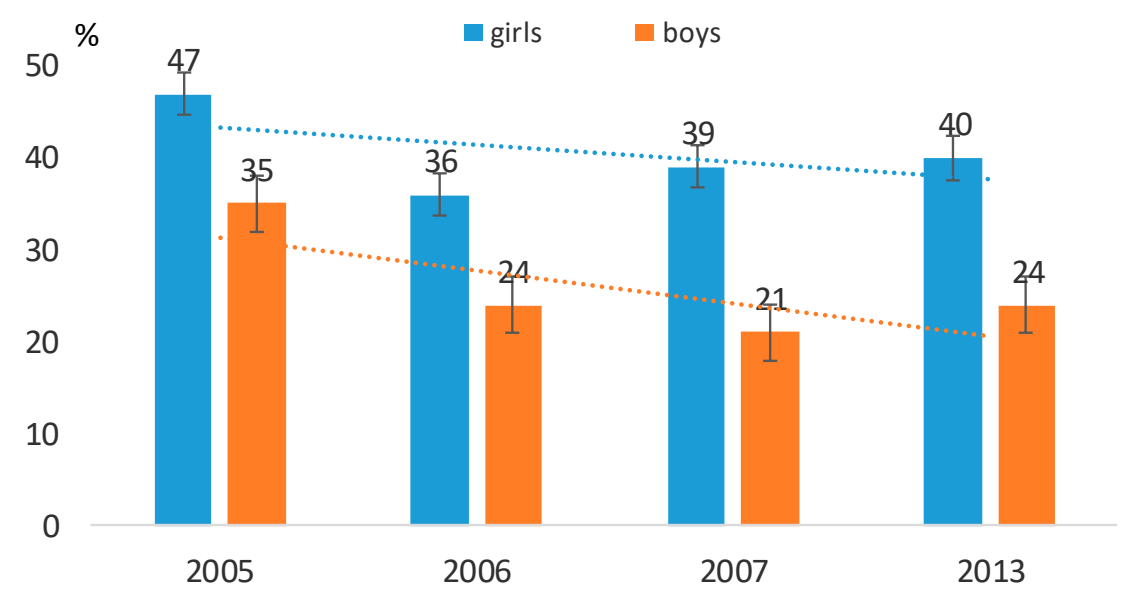

Figure 2. Students with health disorders significantly affecting physical activity by gender 
Although there was a visible tendency of health improvement in students, it was not significant. While assessing the patterns of health disorders affecting physical activity, similar trends were identified both in girls and boys (fig. 3, 4).

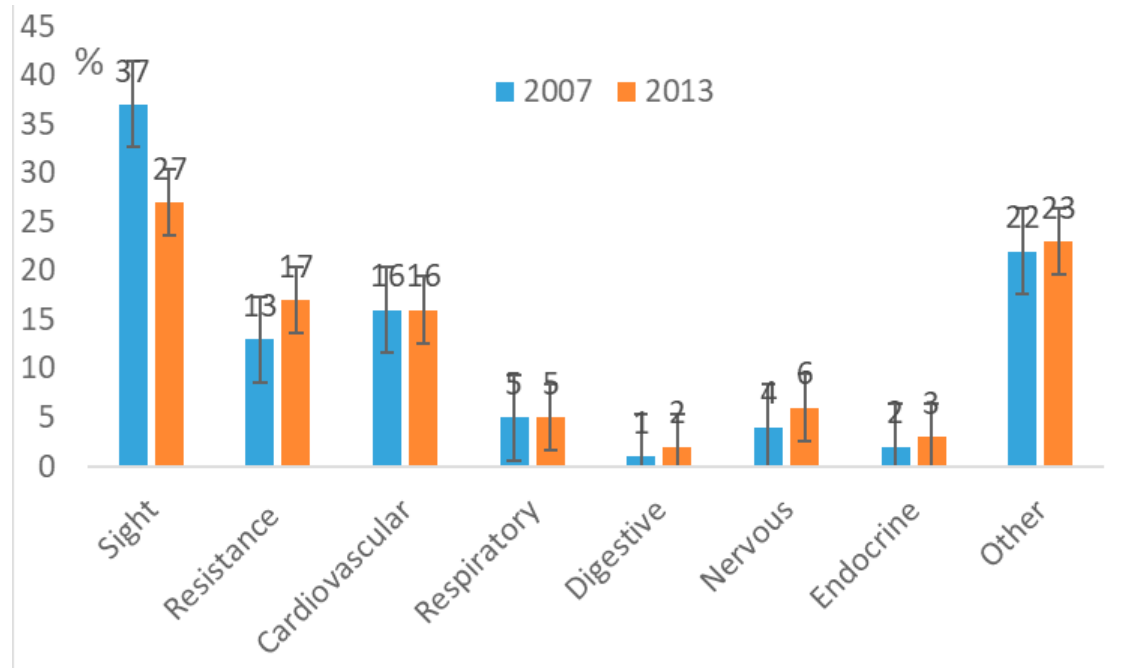

Figure 3. Physical disorders affecting students (girls) in the special group and those exempted from physical education

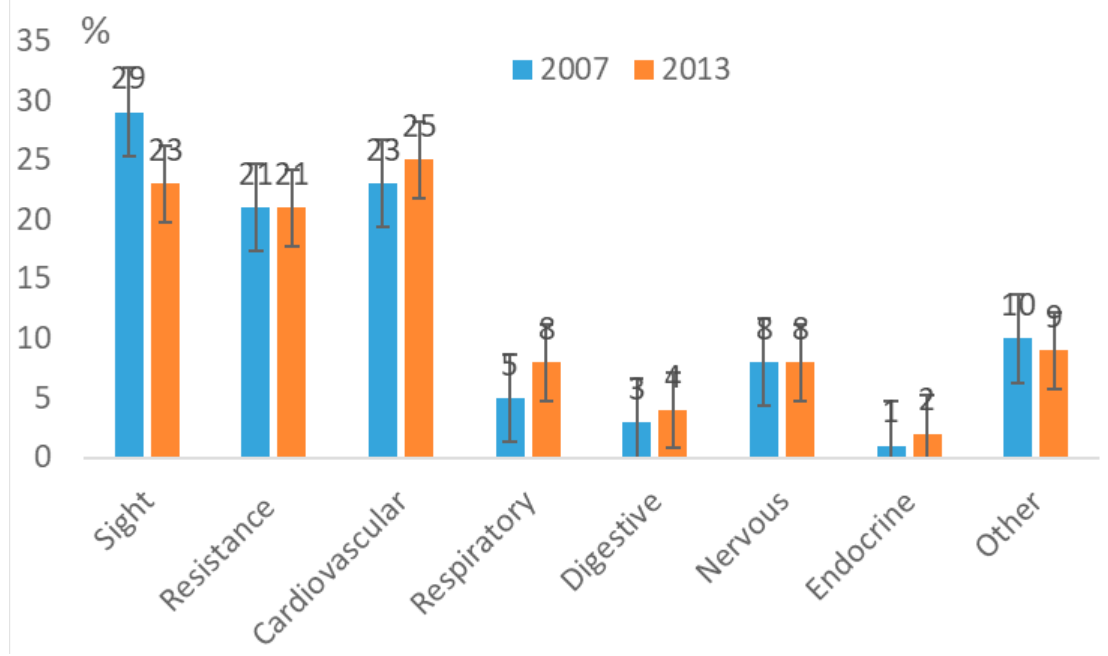

Figure 4. Health disorders affecting students (boys) in the special group and those exempted from physical education

Several health disorders that significantly influenced physical activity in students were identified in the analysed in the period, i.e. 2007-2013. Physical, visual and cardiovascular disorders affected the amount of FA most. However, the patterns and dynamics of these complications in girls and boys were different. It was found that visual disorders were significantly more common in girls (Fig. 5). 


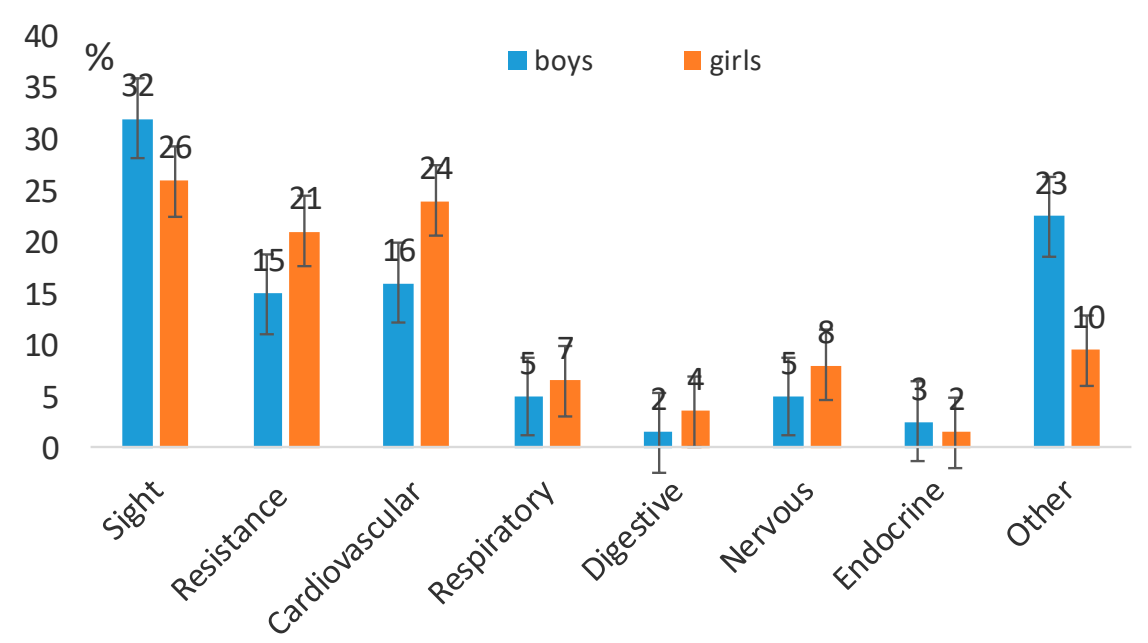

Figure 5. Health disorders in students (boys and girls) in the special group and those exempted from physical education in the years 2007-2013

Still, the sight problems related to the visual system in girls tended to decrease during the study period. Boys, when compared to girls, had more severe health disorders associated with the motor and cardiovascular systems. While evaluating the health indicators of boys who chose additional courses of physical education, it was found that the students with motor disorder tended to do more physical education classes.

Further, it was discovered that the courses of physical education were chosen by 709 students $(9 \%$ of the undergraduate full-time students) in the academic year 2013/14. Taking into account the fact that the training at this level covers eight semesters, it was likely that up to four thousand students at the first-degree level would be enrolled in FA classes, which accounted for about $55 \%$ of the university students.

While comparing the students' health condition at university faculties and the quantitative indicators of those who chose optional courses of physical education, it was noted that students with better health indicators were more active in opting for additional physical education courses ( $r=0.6819 ; p<0.05)$ (Fig. 6).

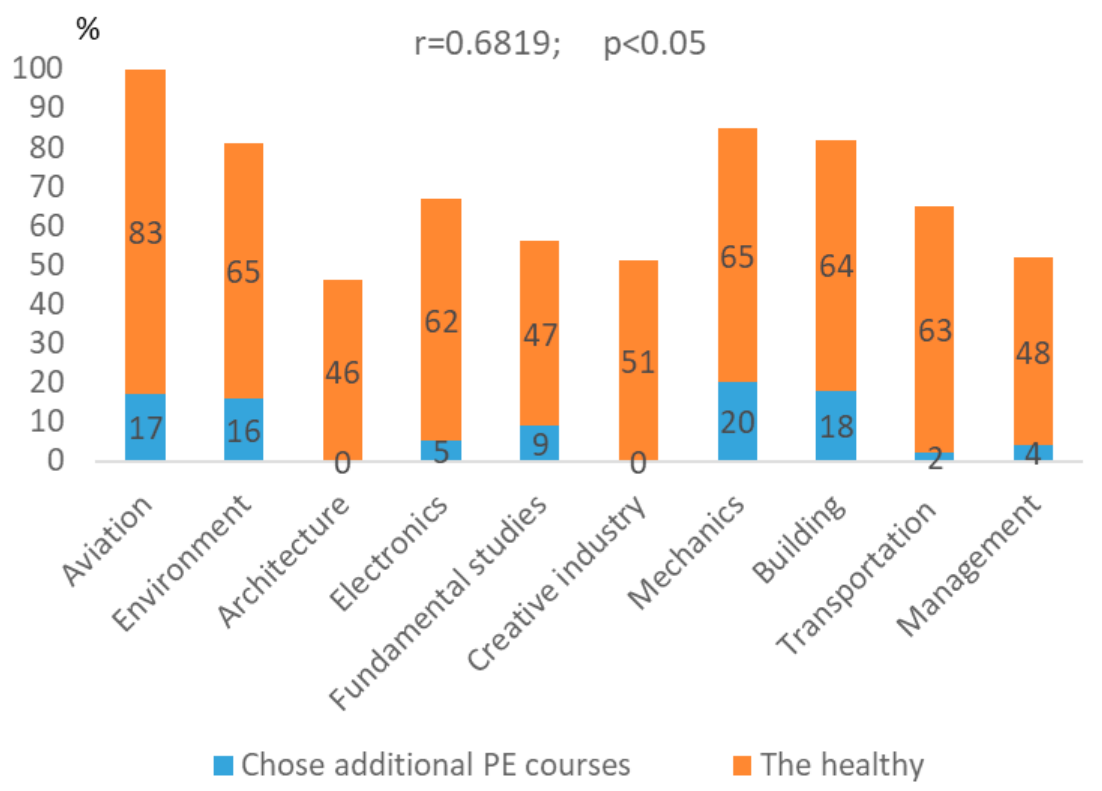

Figure 6. Healthy students' indicators and those who chose additional courses of physical education

Thus, it could be assumed that students with inferior health indicators tended to avoid physical education classes, and the university arrangements were conducive to the process. However, prove or disprove this assumption, more accurate research is needed. 


\section{Discussion}

The health examination of Lithuanian students conducted from the year 1952 and continued until 1987 [11, 12] showed that their health condition was critical. Systematic studies reported that additional physical activity could significantly improve the health and well-being of Lithuanian students [13]. Later studies also showed worrying results, as they indicated an increase in the number of girls and boys suffering from ill health in schools [14]. The following research showed that a significant increase in the number of students exempted from physical education was visible between 1995 and 2005 and that the overall physical condition of Lithuanian students deteriorated [15]. Other studies indicated that girls' health outcomes were worse than the boys' ones [16]. However, the other authors' findings pointed to the fact that girls' lifestyle and attitudes to health were more conducive to preserving health than boys', although their health condition was less satisfactory [17].

The processes of health deterioration in the Lithuanian youth described above could have been caused by the decline in the health of school children [18]. The research done by the author confirms the fact that the Lithuanian youth's health condition and health-related behaviours were dynamic. In all, the health condition of the Lithuanian society tended to deteriorate, especially in its youth. The process had been long and the negative factors should be corrected at various levels of social life (state institutions, private organisations, families, individuals). As regards the formation of healthy lifestyles in the Lithuanian population, it turns out that physical activity should be promoted, as only $17.2 \%$ of the Lithuanian university provide students with a sufficient amount of physical activity [19].

Suitably chosen and diversified physical activity forms (in their intensity, volume, specificity of movement), constitutes a prerequisite in restoring physical activity in students, enhancing health and increasing exercise capacity in the physical and mental health areas [20]. Physical self-education is also of great importance in the field of physical activity [21]. Students' health and physical condition are mainly dependent on physical education. Health-related behaviours acquired at an early age may significantly impact the subsequent life events [22, 23].

\section{Conclusions}

The study showed that about $60 \%$ of students in VGTU were healthy and that the boys' health indicators were better when compared to girls. The most common disorders in students included the ones of visual, cardiovascular and motor system systems, which significantly affected physical activity. The disorders in the motor system might impact the choice of additional physical education courses most, and this opportunity may make students take measures to reduce the harmful health condition. This premise needs to be further researched. A well-designed physical education programme may motivate students to get involved in more physical activity and consequently help to solve health-related problems in the Lithuanian students.

\section{References:}

1. Dadelo S. Sveika gyvensena. Vilnius: Technika; 2015 (in Lithuanian).

2. Mueller M, Morgan D. New insights into health financing: First results of the international data collection under the System of Health Accounts 2011 framework. Health Policy. 2017; 12(7): 764-769.

3. Su S, Pi J, Xie H, Cai Z, Weng M. Community deprivation, walkability, and public health: Highlighting the social inequalities in land use planning for health promotion. Land Use Policy. 2017; 67: 315-326.

4. Barczykowska E, Ślusarz R, Lewicka M, Lewandowska B, Kurylak A. Evaluation of paediatric injury hospitalization incidence at Hospital Ward in Grudziądz. Journal of Education, Health and Sport. 2016; 6(4): 429-446.

5. Dadelo S, Tamošauskas P. Vilniaus Gedimino technikos universiteto pirmo kurso studentų sveikatos įvertinimas. Visuomenès sveikata. 2008; 2(41): 63-69 (in Lithuanian).

6. Bergier J, Bergier B, Tsos A. Variations in physical activity of male and female students from the Ukraine in health-promoting life style. Annals of Agricultural and Environmental Medicine. 2017; 24(2): $217-221$.

7. Dadelo S, Tamošauskas P, Podlužnas V. Vilniaus Gedimino technikos universiteto pirmo kurso įvairių specializacijų studentų palyginamoji sveikatingumo analizė. Visuomenès sveikata. 2009; 1(44): $78-87$ (in Lithuanian).

8. Haag H, Haag G. in cooperation with Birte Kaulitz. From Physical Fitness to Motor Competence. AimsContent-Methods-Evaluation. Sports Sciences International Vol. 3. Frankfurt: Lang; 2000.

9. Dadelo S, Dadelienė R. Взаимосвязь показателей здоровья студентов с выбором дисциплин физической культуры (Relationship of students' health indices with the choice of physical culture disciplines). 
Социологические исследования Москва: Международная книга. 2014; 11: 108-113 (in Russian).

10. Karpavičienė D, Švedas E, Švedienė L, Vorobjova S, Užlienė I, Rožanskienė E, et al. Kūno kultūra silpnesnės sveikatos moksleiviams. Vilnius: Lietuvos respublikos švietimo ir mokslo ministerija; 1999 (in Lithuanian).

11. Вегертас 3. Динамика и некоторые особенности физического развития студентов г. Каунаса по данным обследования 1952-1962. Диссертация. Каунас. 1963 (in Russian).

12. Вегертас 3. Физическое развитие студентов по данным 1955-1987 г. г. Проблемы развития людей разного возраста: тезисы докладов республиканской научной конференции. Каунас. 1988 (in Russian).

13. Скерневичене ВБ. О совершенствовании методики занятий по физическому воспитанию со студентками подготовительного отделения. Дисертация. Вильнюс. 1973; 32-40 (in Russian).

14. Zlatkuvienė L, Černiauskienè M, Žilinskienė E, Katulienė G. Vilniaus pedagoginio instituto studentų sveikata. Socialiniai sveikatos aspektai, 1992; 33-36 (in Lithuanian).

15. Poteliunienė S, Kudaba D. Studenčių fizinės būklès kaita per 1995-2005 metus. Sporto mokslas. 2007; 3(49): 42-46 (in Lithuanian).

16. Mertinas J, Tinteris M. Vilniaus pedagoginio universiteto I kurso studentų sveikatos būklè 1994-1998 metais. Žmogaus ugdymo problemos šiuolaikinèje visuomenėje. Tarptautinė mokslinė konferencija. Mokslo darbai; 1998. p. 194-197 (in Lithuanian).

17. Gustaitienė L, Mykolaitytė D. Studentų sveikatos kontrolès vietos ir sveikatai palankios elgsenos tyrimas. Visuomenès sveikata, 2007. 4(39): 7-13 (in Lithuanian).

18. Juškelienè V. Sveikata ir fizinis aktyvumas. Vilnius: VPU; 2007 (in Lithuanian).

19. Armonienè J. Jaunimo fizinio aktyvumo ugdymo veiksniai. Vilnius: VU; 1998 (in Lithuanian).

20. Anderson ES, Wojcik JR, Winett RA, Williams DM. Social-Cognitive Determinants of Physical Activity: The Influence of Social Support, Self-Efficacy, Outcome Expectations, and Self-Regulation Among Participants in a Church-Based Health Promotion Study. Health Psychology Copyright. 2006; 25(4): 510-520.

21. Olmedilla A, Toro EO, Abenza L. Self-concept, sport, and physical activity practice in university students. Journal of Human Sport \& Exercise. 2016: 11(4): 415-425.

22. Koetting C, Freed P. Educating Undergraduate Psychiatric Mental Health Nursing Students in Screening, Brief Intervention, Referral to Treatment (SBIRT) Using an Online, Interactive Simulation. Archives of Psychiatric Nursing. 2017; 31(3): 241-247.

23. Dadelo S, Turskis Z, Zavadskas EK, Kačerauskas T, Dadelienè R. Is the evaluation of the students' values possible? An integrated approach to determining the weights of students' personal goals using multiplecriteria methods. Eurasia journal of mathematics, science and technology education. 2016; 12(11): 27712781. 